Voix et Images

voixetimages

\title{
Poèmes inédits de Fernand Ouellette
}

\section{Fernand Ouellette}

Volume 5, numéro 3, printemps 1980

Fernand Ouellette

URI : https://id.erudit.org/iderudit/200226ar

DOI : https://doi.org/10.7202/200226ar

Aller au sommaire du numéro

Éditeur(s)

Les Presses de l'Université du Québec

ISSN

0318-9201 (imprimé)

1705-933X (numérique)

Découvrir la revue

Citer ce document

Ouellette, F. (1980). Poèmes inédits de Fernand Ouellette. Voix et Images, 5(3),

477-482. https://doi.org/10.7202/200226ar d'utilisation que vous pouvez consulter en ligne.

https://apropos.erudit.org/fr/usagers/politique-dutilisation/ 


\section{Poèmes Inédits de Fernand Ouellette}

\section{LA MARIÉE}

Le cœur s'effrite en son abîme de fleurs et de venins.

Viennent les vents, les nuées, retombent les poussières, les pétales.

On vieillit d'avoir rêvé...

Jamais plus la mariée ne viendra descellée ou transparente.

Le corps s'en va voûté, noirci d'avoir si mal aimé.

Le front se ferme, s'appuie au silence qui lentement ronge la mémoire.

Un à un les souvenirs, ainsi que des feux à l'orée de l'âme, flambent et retournent en la nuit.

$\mathrm{Ne}$ fut-ce que le temps d'un éclat, s'allumera-t-il notre frais désir, brülera-t-il ce qui s'ouvrait, espérait ot croyait vivre? 


\section{LE BLEU}

Plutót que de franchir le jour:

devenez aveugles!

Ou bien de glisser dans la mer

(comme une femme dans le velours).

Là-bas au devant du désir. là-bas sur limmensité

qui largement respire

(ainși que la mère)

et séduit l'oreille :

en ce bleu tout est leurre,

ce bleu si bleu visage de la mort. 


\section{LE SILENCE}

Les tourments de l'esprit ont bien pele la terre.

Comme les arbres se taisent en leurs branches sans ailes, corps dressés qui n'ondoient mais aspirent a leur ombre, à leur source.

(Le végétal n'aurait-il droit à sa pensée?) Espace sans fleurs et sans tombeaux que la mort ne parvient a rejoindre. Silence des sillons, et travaif du pollen. 


\section{L'AUTRE}

Par les pensées, une à une, le vide m'appelle, me tire: tandis que l'autre se retourne, se glace, infuse des poisons.

Ai-je déjà la tête dans la vase? Les poissons fuient mes rumeurs. On me lapide depuis la rocaille d'une mémoire étente. Je n'entends plus les paysages. Le soleil, la lune s'encrouent l'un sur l'autre.

J'ai perdu ma force d'oiseau. Mon cœur s'éboule dans un fracas. Et quelle dureté écrasant ma parole! 


\section{LE NORD}

Tout ce soleil qui submerge toute chair, toute espérance.

On se donne, en ces jours, a l'arbre qui informe.

Surtout que la mort s'aventure, ose offrir son miroir.

Ca nous renvoie une image (difforme en ses ronds d'étang) de nénuphar qui s'étiole.

Comment se reconnaître?

Alleurs qui ne fulgure quand l'assaille le torrent d'avril?

En deçà, tout l'être se disloque (ó pauvreté noire sur la roue) Par la clameur du regard. Des années se succèdent comme bougent les ombres.

N'importe! si on pense l'oiseau. Qu'il pointe où le Nord le porte! Là-bas, paraît-il, la nuit a le poids moins dur sur l'aile. 


\section{HORS DU MONDE}

La fauvette que frappe le vertige. trace des festons en quittant l'arbre.

Ici la vie se maintient sur la pointe de la mort. Le mepris pour les murs! Le grésillement des regards avant de s'éteindre...

(Tant de bleu naguère sur l'épaule de femmes franches qui traversent l'oreille avec le son de Vermeer.)

Tous les paysages se ferment, ou explosent dans la mémoire, ou s'epandent par les brouillards. Même la montagne se renverse en la mer pour ne plus rien entendre.

Fernand OUELLETTE

N.D.L.A.: Ces poèmes Inédits paraîtront bientôt dans un second tome de la collection *ä́trospective", intitulé En la nuit, la mer, aux éditions de l'Hexagone. 